\title{
CONCEPTUAL AND TERMINOLOGICAL BASICS OF GEOLOGISTICS AS AN ACTUAL DIRECTION OF HUMAN GEOGRAPHY
}

\author{
'Volodymyr GRYTSEVYCH, ${ }^{2}$ Mariana SENKIV \\ 'Ivan Franko National University of Lviv, Ukraine \\ ${ }^{2}$ Lviv Polytechnic National University, Ukraine \\ 'gvsmg@ukr.net, ${ }^{2}$ mariana.i.senkiv@lpnu.ua
}

\begin{abstract}
Perspective directions of geologistic research are singled out in the article based on logistic and geologistic domestic and international research literature. We found out that the concept of geologistics, unlike the concept of logistics, is still not sufficiently developed both in Ukraine and abroad. In the paper, geologistics is defined as a new interdisciplinary scientific and practical direction that examines human-geographical factors and geospatial organization of territorial logistic systems to optimize it. The authors considered conceptual and terminological apparatus of geologistics and formulated the object and subject of geologistics as a science, as well as its relation to human geography. We define territorial logistic system to be the object of geologistics, and the subject of geologistics is represented by human-geographical factors and geospatial organization of territorial logistic system to optimize it. The territorial logistic system as the central concept of geologistics is defined as interrelated set of specialized economic entities and infrastructure, united by certain territorial community, to achieve the efficiency of passenger, commodity, information and financial flows. The object and subject of transport geologistics and distributive geologistics are determined in the article as well. We created the graphic model of semantic network of the conceptual and terminological apparatus of geologistics, and outlined the scientific methodological, material and infrastructural support of the territorial logistic system, as well as the main groups of its functions.
\end{abstract}

Key words: geologistics, territorial logistic system, subjects of logistic activity, logistic infrastructure, logistic functions.

DOI: https://doi.org/10.17721/2413-7154/2017.78.53-59

UDC: 911.3

\section{ПОНЯТТЄВО-ТЕРМІНОЛОГІЧНІ ОСНОВИ ГЕОЛОГІСТИКИ ЯК АКТУАЛЬНОГО НАПРЯМКУ СУСПІЛЬНОЇ ГЕОГРАФІЇ}

\author{
'Володимир ГРИЦЕВИЧ, ²Мар'яна СЕНЬКІВ \\ 'Львівський національний університет імені Івана Франка, Україна \\ ${ }^{2}$ Національний університет "Львівська політехніка», Україна \\ 'gvsmg@ukr.net, ${ }^{2}$ mariana.i.senkiv@lpnu.ua
}

\begin{abstract}
Анотація: Вивчено джерельну базу логістичних та геологістичних досліджень в Україні та за кордоном. Виділено перспективні напрямки геологістичних досліджень. Розглянуто поняттєво-термінологічний апарат геологістики. Сформульовано об'єкт та предмет дослідження гелогістики як науки, а також її відношення до суспільної географії та логістики. Визначено територіальну логістичну систему як центральне поняття геологістики і подано її дефініцію. Визначено об'єкт та предмет дослідження транспортної геологістики та розподільчої геологістики. Створено графічну модель семантичної мережі поняттєво-термінологічного апарату геологістики. Розглянуто науково-методичне, субстанційне та інфраструктурне забезпечення територіальної логістичної системи, а також головні групи її функцій.
\end{abstract}

Ключові слова: геологістика, територіальна логістична система, суб'єкти логістичної діяльності, логістична інфраструктура, логістичні функції.

DOI: https://doi.org/10.17721/2413-7154/2017.78.53-59

UDC: 911.3

Постановка проблеми. Поняття геологістики, на відміну від поняття логістики, є поки що недостатньо розробленим як в Україні, так і за кордоном. Більшість авторів відносять геологістику до логістичних концепцій третього покоління (поч. XXI ст.), визначаючи їі як теорію і практику територіальноекологічної оптимізації логістичних систем різних

(C) В. Грицевич, М. Сеньків масштабів шляхом збуту продукції. Проблема полягає в тому, що немає чітких однозначних визначень, які пов’язували б геологістику із суміжними науками, також немає єдності у розумінні головних термінів геологістики.

Аналіз останніх досліджень і публікацій. Фундаментальною працею у сфері логістики та управління ланцюгами поставок $\epsilon$ підручник “Стратегічне управління логістикою" американ- 
ських учених Дж. Стока і Д. Ламберта [15], а також праці вчених Д. Бауерсокса та Р. Баллоу [1, 19]. Геологістичні дослідження у світі часто представлені у працях географів. Зокрема, відомі суспільні географи Дж.-П. Родріге і М. Гессе дослідили зв’язок між управлінням ланцюгами поставок, логістикою i географією транспорту, зокрема, виділили такі географічні форми логістики: потоки, вузли i мережі [22]. Цікавою для геологістики є праця Дж.-П. Родріге "Географія транспортних систем", в одному з розділів якої йдеться про застосування ГІС у транспорті [25], а також стаття цього ж вченого про географію глобальних ланцюгів поставок [24]. Деякі аспекти геологістичних досліджень представлені у працях вчених Асоціації американських географів, зокрема, у працях вченої кафедри географії i планування Університету Торонто Д. Ковен [20, 21]. Регіональні аспекти геологістики представлені в публікації В. Грицевича та М. Сеньків [23].

Детально проаналізувавши сучасні вітчизняні наукові праці, можемо виділити сім поширених напрямків досліджень суспільних географів із геологістики в Україні: 1) теоретичні та науковопрактичні основи геологістики; 2) суспільногеографічні передумови логістичної діяльності; 3) процеси інтеграції України у європейську транспортно-логістичну систему; 4) геопросторові аспекти аграрної логістики; 5) геопросторові аспекти митної логістики; 6) геопросторові аспекти логістики туризму; 7) екологічні аспекти геологістики.

Перший напрямок геологістичних досліджень в Україні представлений науковими працями проф. I. Смирнова [12], зокрема, його докторською дисертацією, в якій розроблені теоретичні та практичні основи логістичного напряму в суспільній географії. Цікавою у контексті дослідження теоретичних i науково-практичних основ геологістики $є$ публікація проф. I. Смирнова та проф. О. Топчієва "Просторові структури у суспільно-географічній логістиці i методи їх аналізу" [14], в якій обгрунтовані принципи аналізу територіальних логістичних мереж. Характеристика математичних методів, які широко застосовуються в геологістиці, представлена в роботах проф. О. Шаблія та В. Грицевича $[17,2]$.

Другий напрямок досліджень 3 геологістики в Україні досить широко представлений у роботах вчених-географів О. Борисюк, О. Бордун, В. Грицевича, К. Діденко, Д. Мальчикової, М. Мацяха, Н. Нефедової, С. Отечка, Н. Пашинської, І. Рудакевича, О. Топчієва, О. Шаблія та ін.

Дослідженню процесів інтеграції України у європейську транспортно-логістичну систему присвячені кандидатські дисертації вчених I. Шум та Л. Литвиненко, а також наукові статті проф. І. Смирнова. В роботі I. Шум [18] розроблені теоретико-методологічні та прикладні суспільно-географічні основи інтеграції України в пан'європейську транспортно-логістичну систему, а в роботі Л. Литвиненко визначені та охарактеризовані основні напрямки інтеграції України в Балто-Чорноморську транспортно- логістичну систему як складову пан'європейської транспортно-логістичної інтеграції [7].

Сутність та особливості геопросторових аспектів розвитку аграрної логістики в Україні та світі розкриті в дисертаційній роботі О. Качур [4], де автор також розробила теоретико-методичні основи та бізнесово-практичні напрямки формування та функціонування вітчизняних агрологістичних систем з урахуванням світового досвіду.

Концептуальні основи митної логістики, зокрема, iii компонентної, регіональної та функціональної структур в умовах України та їі євроінтеграційного курсу, розкриті у статті проф. І. Смирнова [13].

Дослідженню територіальних аспектів логістики туризму присвячені наукові публікації І. Смирнова [11]. Варто також відзначити навчальний посібник “Логістика туризму” проф. I. Смирнова [10].

Питанню екологічних аспектів геологістики присвячена наукова стаття проф. I. Смирнова [9], у ній також проаналізована конкретна програма “зеленої логістики”.

Завданням цього дослідження $є$ визначення місця геологістики в системі наук загалом, у 3'ясуванні ㄲï зв'язку 3 найближчими науковими дисциплінами - суспільною географією та логістикою, а також в уточненні значення головних термінів та їхнього взаємозв'язку в системі поняттєво-термінологічного апарату геологістики. Окремого розгляду заслуговують транспортна та розподільча геологістика.

Виклад основного матеріалу. Поняттєвотермінологічний апарат (ПТА) геологістики перебуває в стані формування. Поняття і терміни, якими оперує геологістика, здебільшого запозичені 3 географії транспорту і логістики.

Проф. І. Смирнов застосовує поняття "суспільногеографічна логістика" (в англомовних джерелах geologistics). На його думку, суспільно-географічна логістика - це новітній міждисциплінарний науково-практичний напрям, що формується на межі логістики та суспільної географіï, i досліджує наукову організацію (у сучасному логістичному розумінні) територіально-економічних (або ширше географічно-просторових) зв'язків і відношень [12].

На думку вчених О. І. Ільєнко і О. К. Катерни, геологістика - це новітній напрямок у логістиці, який полягає у формуванні і розподілу світових транспортних потоків, а також відстеженні їх у реальному режимі часу із застосуванням сучасних ГІС 3 метою знаходження оптимальних рішень, забезпечуючи об'єднання процесів функціональних структур підприємства в єдину систему [3].

Ми визначаємо геологістику як новий міждисциплінарний науково-практичний напрямок, що досліджує суспільно-географічні чинники та геопросторову організацію територіальних логістичних систем i створюваних ними пасажирських, вантажних, інформаційних і фінансових потоків для ㄲï оптимізації. У цій статті геологістика є синонімом суспільно-географічної логістики. Вважаємо, що геологістика бере об'єкт свого дослідження 3 логістики, а предмет 
дослідження - з суспільної географії. У зв’язку з цим виникають такі формулювання.

Об'єктом дослідження геологістики є територіальні логістичні системи (ТЛС). На нашу думку, ТЛС є центральним поняттям геологістики, навколо якого виникають інші поняття. Предметом дослідження геологістики $є$ суспільно-географічні чинники та геопросторова організація ТЛС $з$ метою іii оптимізації.

Транспортна геологістика досліджує суспільно-географічні чинники й геопросторову організацію територіальних логістичних систем i створювані ними пасажирські та вантажні потоки для вибору виду транспорту й визначення оптимальних маршрутів перевезень. Розподільча геологістика вивчає суспільно-географічні чинники й геопросторову організацію територіальних логістичних систем і створювані ними вантажні потоки для оптимального вибору логістичних каналів, а також оптимального розміщення розподільчих центрів.
На думку проф. Є. Крикавського, логістична система - це адаптивна система із зворотнім зв'язком, що виконує ті чи інші логістичні функції і операції, складається, як правило, 3 декількох підсистем і має досить розвинуті зв'язки із зовнішнім середовищем [5, с. 169]. Проф. М. Окландер пропонує таке визначення логістичної системи: логістична система - це спеціально організована інтеграція логістичних елементів (ланок) у межах певної економічної системи для оптимізації процесів трансформації матеріального потоку [8, с. 15].

На нашу думку, територіальна логістична система (ТЛС) - це взаємопов'язана сукупність спеціалізованих суб'єктів господарської діяльності й інфраструктури, об'єднаних певною територіальною спільністю, для досягнення ефективності пасажирських, вантажних, інформаційних і фінансових потоків. ТЛС $є$ функціональною складовою (підсистемою) територіальної господарської системи. ТЛС може бути регіональною, міжрегіональною, національною та міжнаціональною (рис. 1).

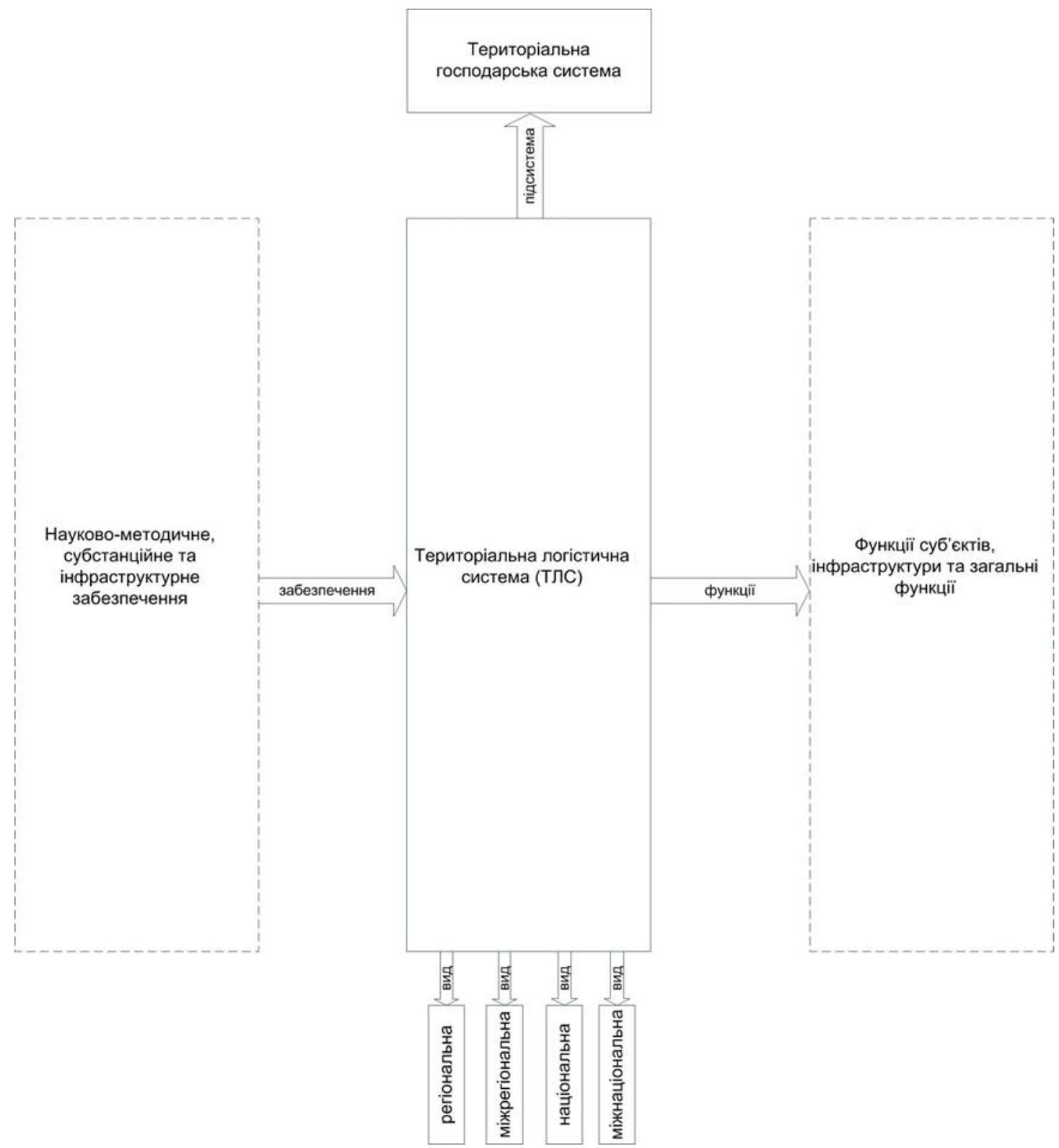

Рис. 1. Центральні поняття семантичної системи ПТА геологістики 
Щодо розуміння поняття “регіональна логістична система" (РЛС) існує декілька підходів. Згідно одного з них, регіональна логістична система - це територіальна організація сфери обігу, де відбувається погодження інтересів виробників та споживачів, що дозволяє поєднати зусилля різних одиниць, виробляючих товари і послуги, 3 метою оптимізації фінансових, матеріальних i трудових ресурсів, які використовує регіон для реалізації своїх економічних цілей [6, С. 12].
На нашу думку, суть РЛС точніше відображена в такому означенні: регіональна логістична система - це форма територіальної організації логістичної діяльності в межах регіону (субрегіону), головними елементами якої $\epsilon$ : взаємозв'язана i взаємообумовлена мережа логістичних центрів різного ієрархічного рівня, багатокомпонентна обслуговуюча інфраструктура, централізована система управління, спрямовані на формування єдиного логістичного простору регіону 3 метою

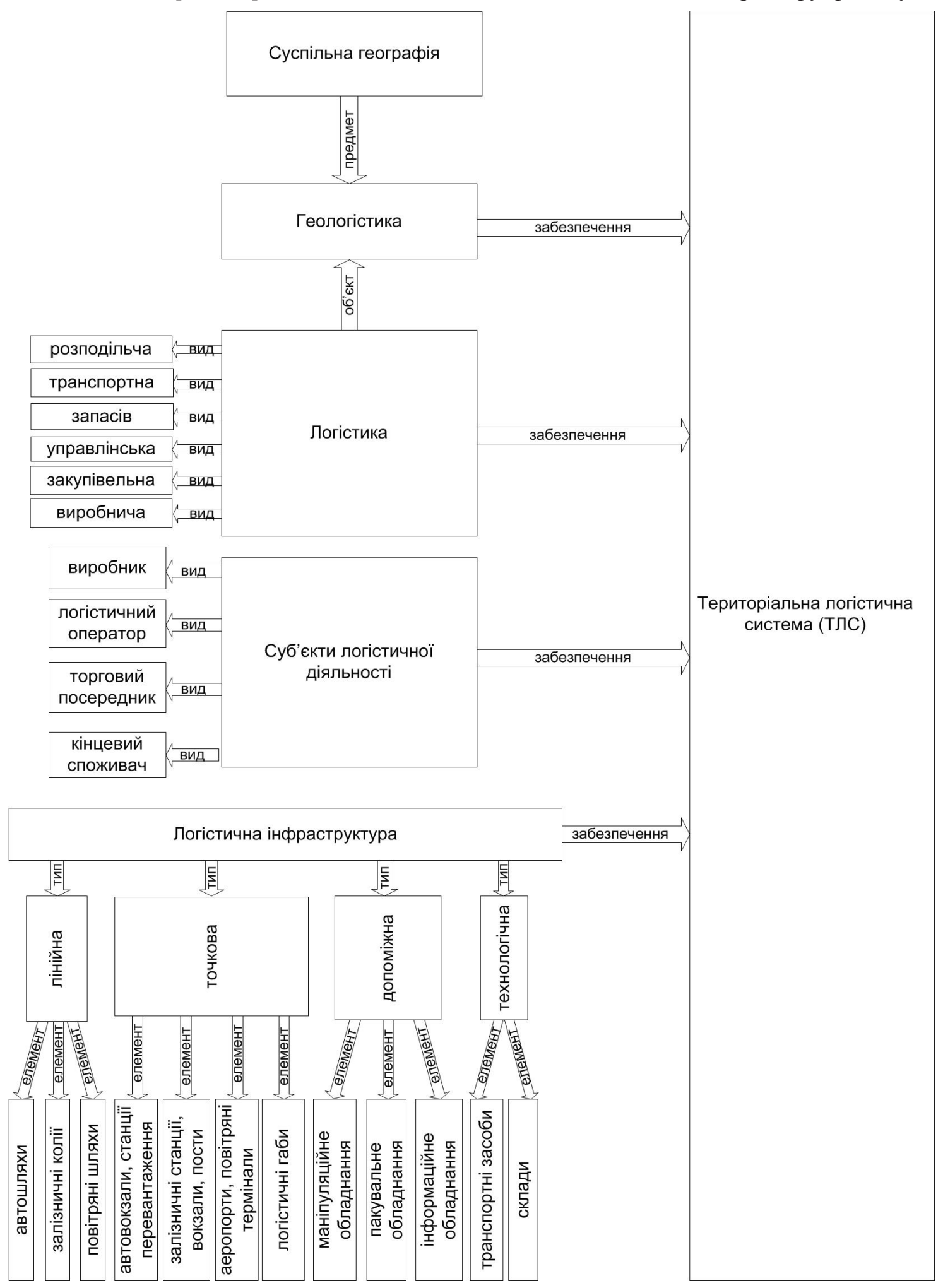

Рис. 2. Науково-методичне, субстанційне та інфраструктурне забезпечення ТЛС 
підвищення ефективності обслуговування матеріальних потоків [16, с. 7].

Ми розуміємо регіональну логістичну систему як взаємопов'язану сукупність спеціалізованих суб'єктів господарської діяльності й інфраструктури регіону для досягнення ефективності пасажирських, вантажних, інформаційних і фінансових потоків. РЛС є функціональною складовою (підсистемою) регіональної господарської системи.
Теоретико-методичнимзабезпеченням функціонування ТЛС $є$ логістика та геологістика, субстанційним забезпеченням ТЛС $є$ суб'єкти логістичної діяльності, інфраструктурним забезпеченням є логістична інфраструктура (рис. 2).

Суб'єкти логістичної діяльності-це виробники, логістичні оператори, торгівельні посередники, кінцеві споживачі.

Логістична інфраструктура є системою засобів перетворення логістичних потоків (матеріальних,

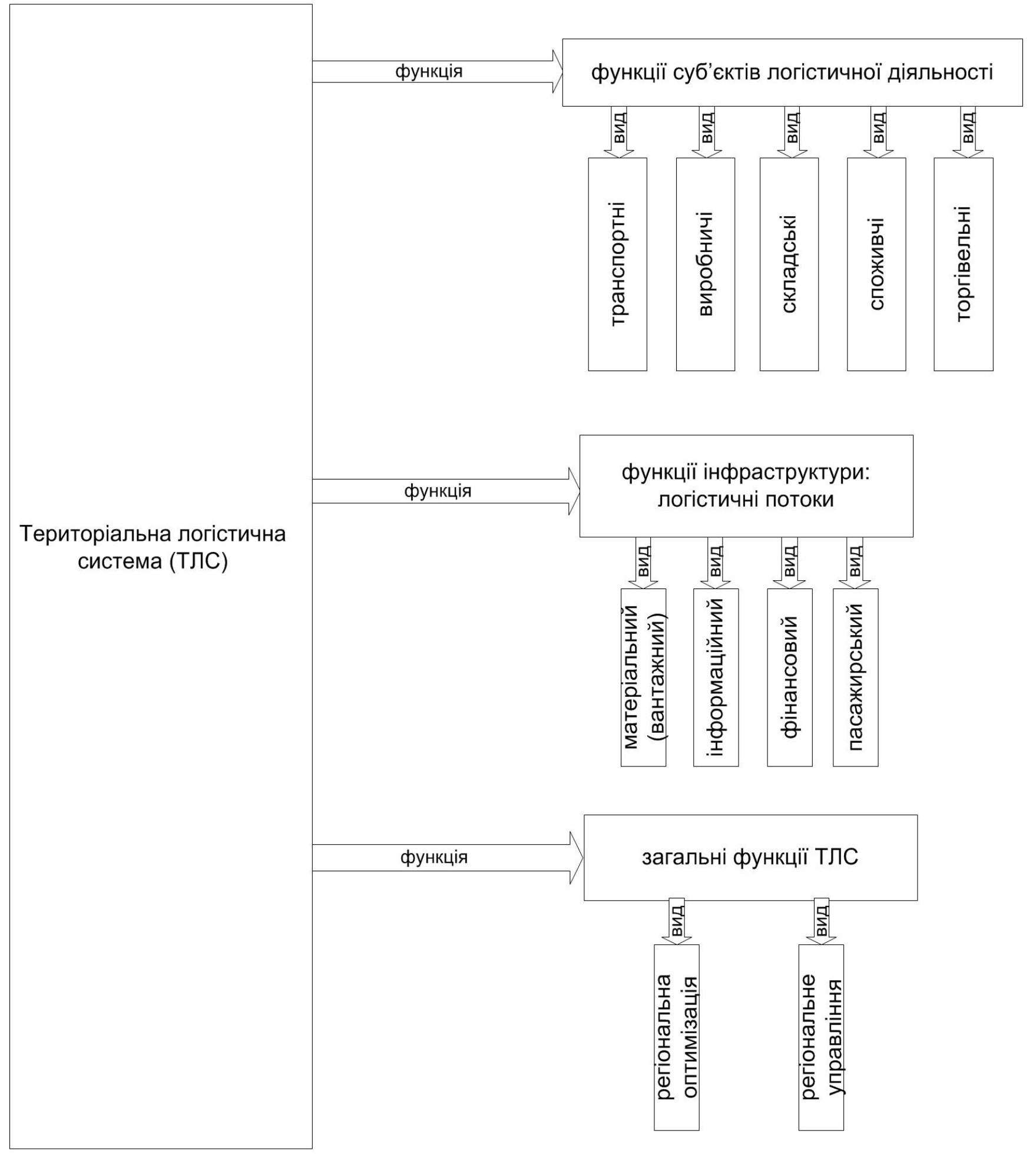

Рис. 3. Функції ТЛС 
інформаційних, фінансових, людських), а також сукупність підприємств різних організаційноправових форм, які створюють організаційноекономічні умови проходження цих потоків шляхом створення потенціалу відповідних логістичних послуг [8, С. 109].

Виділяють технічну та організаційноекономічну складові логістичної інфраструктури. Перша може бути лінійною (автомобільні шляхи, залізничні сполучення, повітряні шляхи, водні шляхи, трубопровідні сполучення), точкова (станції, вокзали, порти, аеропорти, контейнерні термінали; логістичні центри), допоміжна (маніпуляційне обладнання, пакувальне обладнання, інформаційне обладнання), технологічна (різні види та типи транспортних засобів, склади класів A, B, C, D). Організаційно-економічна складова реалізується сукупністю підприємств різних організаційноправових форм, які створюють організаційноекономічні умови проходження матеріальних потоків з метою їхньої оптимізації.

Суб'єкти логістичної діяльності виконують транспортні, виробничі, складські, споживчі, торгівельні функції (рис. 3).

Головною функцією інфраструктури ТЛС є логістичний потік, який розуміємо як територіальну сукупність об'єктів, що існує як процес у деякому часовому інтервалі. Логістичні потоки бувають матеріальними (вантажними), інформаційними, фінансовими, людськими (пасажирськими). Зауважимо, що головними є пасажирські і вантажні потоки, а інформаційні та фінансові є супутніми їм. За відношенням до системи, що розглядається, потоки можуть бути внутрішніми та зовнішніми. Ми виділяємо також загальні функції ТЛС, відносячи до них регіональну оптимізацію i регіональне управління.

Висновки. Геологістика, або суспільногеографічна логістика - це наукова дисципліна на межі суспільної географії та логістики, об'єкт 11i дослідження співпадає з об’єктом дослідження логістики, а предмет дослідження - 3 предметом дослідження суспільної географії. Центральним поняттям геологістики $є$ територіальна логістична система, навколо якої розгортаються інші терміни та поняття. Головним теоретикометодичним забезпеченням діяльності територіальної логістичної системи є логістика та геологістика, субстанційним забезпеченням виступають суб'єкти логістичної діяльності, інфраструктурним - логістична інфраструктура. Головними групами функцій територіальної логістичної системи є функції суб'єктів логістичної діяльності, функції логістичної інфраструктури (логістичні потоки) та загальні функції.

\section{References:}

1. Baujersoks D. Dzh. Logistika : integrirovannaja cep’ postavok [Logistics: integrated supply chain]. Moscow, 2008, 640 p. (In Russian).

2. Gricevič V. S. Matematični metodi v suspil'nìj geografi [Mathematical methods in human geography]. Lviv, 2013, 48 p. (In Ukrainian).

3. İl'ênko O. V. Geologìstika [Geologistics]. Kyiv, 2013, 284 p. (In Ukrainian).

4. Kačur O. V. Geoprostorovij aspekt agrologìstiki na mižnarodnomu ta nacional'nomu rìvnâh [Geospatial aspect of agrologistics at the international and national levels]. Author's abstract from PhD thesis. Kyiv, 2015, 22 p. (In Ukrainian).

5. Krikavs'kij Ê. V. Formuvannâ ekonomičnogo potencialu pìdpriêmstv na osnovi logìstičnih koncepcìj [Formation of economic potential of enterprises on the basis of logistic concepts]. Author's abstract from PhD thesis. Lviv, 1997, 47 p. (In Ukrainian).

6. Larìna R. R. Teoretiko-metodologičnì osnovi formuvannâ regional'nih logističnih sistem [Theoretical and methodological foundations of the formation of regional logistic systems]. Author's abstract from PhD thesis. Kharkiv, 2006, 34 p. (In Ukrainian).

7. Litvinenko L. M. Ukraïna v sistemi Balto-Čornomors'koï transportno-logìstičnoï integracï : suspil'nogeografičnij vimìr [Ukraine in the system of Baltic and Black Sea transport and logistic integration : humangeographical dimension]. Author's abstract from PhD thesis. Kyiv, 2010, 20 p. (In Ukrainian).

8. Oklander M. A. Formuvannâ logìstičnih sistem pidpriêmstv [Formation of logistic systems of enterprises]. Author's abstract from $\mathrm{PhD}$ thesis. Odesa, 2003, 39 p. (In Ukrainian).

9. Smirnov İ. G. “Zelena logìstika": suspill'no-geografičnij aspekt ["Green Logistics" : human-geographical aspect]. Naukovij visnik Volins’kogo deržavnogo universitetu imeni Lesi Ukrä̈nki. Geografični nauki [Scientific bulletin of Lesia Ukrainka State University of Volyn. Geographical sciences]. Lutsk, 2001, pp. 10-15. (In Ukrainian).

10. Smirnov Ì. G. Logistika turizmu [Logistics of tourism]. Kyiv, 2009, 444 p. (In Ukrainian).

11. Smirnov İ. G. Logìstična model' stalogo rozvitku turističnogo bìznesu [Logistic model of sustainable development of tourist business]. Visnik nacional'nogo universitetu 'L'vivs 'ka politehnika" [Bulletin of Lviv Polytechnic National University]. Lviv, 2007, pp 158-162. (In Ukrainian).

12. Smirnov Ì. G. Logìstičnij naprâm v suspill'nìj geografï : teorîa ì praktika doslidžennâ [Logistic direction in human geography : theory and practice of research]. Author's abstract from PhD thesis. Kyiv, 2004,33 p. (In Ukrainian). 
13. Smirnov İ. G. Mitna logistika : kartografičnij aspekt [Customs logistics : cartographic aspect]. Časopis kartografiï [Cartography journal]. Kyiv, 2011, pp 168-187. (In Ukrainian).

14. Smirnov İ. G. Prostorovì strukturi u suspil'no-geografičnìj logìsticì ì metodi ïh analizu [Spatial structures in human-geographical logistics and methods of its analysis]. Geoìnformatika [Geoinformatics]. Kyiv, 2006, pp. 20-25. (In Ukrainian).

15. Stok Dzh. R. Strategicheskoe upravlenie logistikoj [Strategic management of logistics]. Moscow, 2005, 797 p. (In Russian).

16. Tarakanov N. L. Regional'nye logisticheskie sistemy : problemy formirovanija i razvitija [Regional logistics systems : problems of formation and development]. Odesa, 2013, 311 p. (In Russian).

17. Šablij O. İ. Matematičnì metodi v social'no-ekonomičnij geografiï [Mathematical methods in social and economic geography]. Lviv, 1994, 303 p. (In Ukrainian).

18. Šum İ. V. Suspil'no-geografičnì aspekti integracï̈ Ukraïni v pan'êvropejs'ku transportno-logìstičnu sistemu [Human-geographical aspects of Ukraine's integration into Pan-European transport and logistic system]. Author's abstract from PhD thesis. Kyiv, 2007, 20 p. (In Ukrainian).

19. Ballou R. H., Srivastava S. K. Business Logistics. Supply Chain Management, Pearson Education. London, Dorling Kindersley, 2007, pp. 117-129.

20. Cowen D. A Geography of Logistics : Market Authority and the Security of Supply Chains. The Annals for the Association of American Geographers.Washington, AAG, 2010, pp. 1-21.

21. Cowen D. The Deadly Life of Logistics : Mapping Violence in Global Trade. Minnesota, University of Minnesota Press, 2014, 290 p.

22. Hesse M., Rodrigue J.-P. The transport geography of logistics and freight distribution. Journal of Transport Geography. Amsterdam, Elsevier B. V., 2004, 14 p.

23. Hrytsevych V., Senkiv M. Transport and logistic potential of the Western Ukrainian borderland. Journal of Geography, Politics and Society. Uniwersytet Gdanski, 2017, pp. 81-86.

24. Rodrigue J.-P. The Geography of Global Supply Chains : Evidence from Third Party Logistics. Journal of Supply Chain Management, special issue on "Global Sourcing : Other Voices". Medford, Wiley Periodicals, Inc, 2012, pp. 15-23.

25. Rodrigue J.-P. (ed). The geography of transport systems. Third Edition. London, Routledge, 2013, 416 p. 